\title{
Islam and Innovation: Food Defence and Safety Movement of Ma'had Al-Zaytun Indramayu
}

\author{
$1^{\text {st }} \mathrm{R}$ Tabroni \\ History Education Program Study \\ STKIP Pangeran Dharma Kusuma \\ Segeran Indramayu \\ Hasyim Asy'ari Street No.1/1 Segeran \\ Kidul Juntinyuat Indramayu, West \\ Java, Indonesia \\ roni.tabroni@stkippadhaku.ac.id \\ $4^{\text {th }} \mathrm{W}$ Iryana \\ History Education Program Study \\ STKIP Pangeran Dharma Kusuma \\ Segeran Indramayu \\ Hasyim Asy'ari Street No.1/1 Segeran \\ Kidul Juntinyuat Indramayu, West \\ Java, Indonesia \\ $7^{\text {th }}$ A A Junaedi \\ History Education Program Study \\ STKIP Pangeran Dharma Kusuma \\ Segeran Indramayu \\ Hasyim Asy'ari Street No.1/1 Segeran \\ Kidul Juntinyuat Indramayu, West \\ Java, Indonesia
}

\author{
$2^{\text {nd }}$ Nurhata \\ History Education Program Study \\ STKIP Pangeran Dharma Kusuma \\ Segeran Indramayu \\ Hasyim Asy'ari Street No.1/1 Segeran \\ Kidul Juntinyuat Indramayu, West \\ Java, Indonesia
}

$5^{\text {th }} \mathrm{G} \mathrm{E} \mathrm{Gemini}$

History Education Program Study STKIP Pangeran Dharma Kusuma Segeran Indramayu

Hasyim Asy'ari Street No.1/1 Segeran Kidul Juntinyuat Indramayu, West Java, Indonesia

\author{
$3^{\text {rd }} \mathrm{E}$ N Arovah \\ History Education Program Study \\ STKIP Pangeran Dharma Kusuma \\ Segeran Indramayu
}

Hasyim Asy'ari Street No.1/1 Segeran Kidul Juntinyuat Indramayu, West Java, Indonesia

$6^{\text {th }} \mathrm{S}$ Ma'mun

History Education Program Study STKIP Pangeran Dharma Kusuma Segeran Indramayu

Hasyim Asy'ari Street No.1/1 Segeran Kidul Juntinyuat Indramayu, West Java, Indonesia
Abstract-This article discusses the movement of Ma'had Al-ZaytunIndramayu in fostering food defence and safety for santri, pesantren and surrounding communities. Ma'had Al-Zaytun is one of the modern pesantren which in its development has received pro and contra reactions from various circles. The main controversy was when several circles considered AS Panji Gumilang through Ma'had AlZaytun consistently recruiting members to realize the idea of establishing an Islamic State as Kartosuwiryo did through his Darul Islam. This was then answered by AS Panji Gumilang with innovations in various fields. One of them is to foster food defence and safety starting from oneself, family, santri, pesantren and to the surrounding community. This study uses qualitativemethod with literature review, field research and interviews as collecting data methodsthat collaborated with the theory of resource mobilization to see how AS Panji Gumilang mobilizes various resources, utilizes social networks with other groups, applies flexibly to other groups and has full control for realizing its efforts to foster food defence and safety in the pesantren he leads. The results showed that Ma'had Al-Zaytun was proven not only to bring santri to become Muslims Kaffah but also to succeed in instilling the values of food defence and safety in the hearts of the santri and the surrounding community. It does can be a model in the development of food defence and safety in pesantren and its surrounding communities.

Keywords-Ma'had Al-Zaytun, Food Defence, Food Safety, Pesantren

\section{INTRODUCTION}

Food according to Indonesia Law number 18 of 2012 is anything that comes from biological sources of agricultural products, plantations, forestry, fisheries, livestock, waters, and water, whether processed or not processed which are intended as food and beverages for human consumption, including food additives foodstuffs and other materials used in the preparation, processing and / for the making of food or beverages(1). Food defence itself means the process to ensure the security of food and drink from all forms of intentional malicious attack including ideologically motivated attack leading to contamination (2). From this definition the emphasis is on the protecting your food from internal and external threats. Unlike food defence, food safety regulated in Indonesia Law number 18 of 2012 chapter VII articles 6769, covers food sanitation, regulation of food (BTP), 
regulation of genetically modified food products, regulation of food radiation, stipulation of food packaging standards, providing food safety and food quality guarantees, and guaranteeing halal products for those who are required (1). The principle is ASUH: aman (safe), sehat (healthy), utuh (whole), and halal. Food safety more directed towards efforts to ensure the food is safe to eat and free from dangerous levels of harmful infectious and toxic agents (natural and accidental contamination)(3).

The main food defence problems that emerge later are is a lack of standardized testing material and methods for many of the potential contaminants. Food safety is more problematic, because it deals with so many other problems outside of food itself. These problems include extremist ideology, poverty, and inequality. Food defence and safety are a multi-dimensional topic. It not only talks about protection activities, but also discusses methodology and countermeasures taken to prevent and mitigate the effects of intentional incidents and threats to the food chain. The type of threat that can be addressed by food defence practices can range from food crime, food fraud, tampering, and food terrorism(4).

Referring to the problems that arise in the effort of food defence and safety, what can then be provided by Islam and the culture that surrounds it? Empowering students/santri and the community in a pesantren environment will more or less provide insight into the potential of what this religion can offer. Some research related to the empowerment of pesantren can be found easily, including the business of Pesantren Syafi'iyah alFalah Bungbulang and Pesantren Asem in Sinarjaya Garut where students are not charged with tuition fees and building fees to empower their students. Students only need to bring provisions for their personal lives such as food and clothing. While learning, they are involved in various socio-economic activities that can support their daily needs (5). There is also Pesantren Hidayatullah Deli Serdang, North Sumatra. This pesantren empowers its students in various fields, including; carpentry, hygiene, agriculture and animal husbandry, education, administration and managing the target villages (5). In addition, there is also a study of Faozan (6)which shows that pesantren inhabited by santri/students are quite a number of positive consumers and supported by the surrounding community. That is, students and the community around the pesantren are basically consumers whose needs can be fulfilled economically by pesantren itself. So, pesantren can be independent to become an economic institutional center for students and the surrounding community. From these studies it can be seen that the empowerment of students is not new, but no one has spoken of a pesantren that empowers students and the surrounding environment in terms of food defence and safety. This research seeks to fill the knowledge about how Islam and its pesantren play a role in innovation in the field of food defense and safety.

\section{RESEARCH METHOD}

This study uses qualitative method with literature review, field research, and interviews as collecting data methods. This method then collaborated with the theory of resource mobilization to see how A S Panji Gumilang (the founder and the leader of Ma'had Al-Zaytun) mobilizes various resources, utilizes social networks with other groups, applies flexibly to other groups and has full control for realizing its efforts to foster food security and sovereignty in pesantren he leads.

\section{RESULT AND DISCUSSION}

A. Food defence and safety efforts at Ma'had Al-Zaytun Ma'had Al-Zaytun is one of the modern pesantren that tries to combine religious values with innovation and modernization in various fields. One example is the development of education in the pesantren which took place quickly and now they are transformed into a center of modern education that seeks to apply an integrated education system with the name of a one pipe education system. Modernity of education in Ma'had Al-Zaytun can be seen from the implementation of educational programs that always refer to international qualification standards, such as: the ICDL (International Computer Driving License) program and the ICCS (International Certificate in Computer Studies)(7)This condition is a consequence of their expensive tuition and fees. A situation to answer operational costs that are also expensive. Ma'had AlZaytun's operational costs include boarding and school fees as well as modern supporting facilities. However, what's interesting about pesantren located in Gantar, Indramayu is that the money taken from the santri/students is then processed to become pesantren's income. They then not only did not depend on outside products, but later became producers. Goods produced will not only be enjoyed by students but will also be marketed outside pesantren. This proves that pesantren can become and always be the pioneers or pioneers of the development (economy) of the people in Indonesia, especially in food defence.

Pesantren has three potential pillars to be an economic source for the existence and development of the boarding school; kiai, santri and education. The three pillars will then become important elements to realize the three main functions of a pesantren; first, as a center for the cadre of religious thinkers (center of excellence). Second, as an institution that prints human resources. Third, as an institution that empowers society (agent of development)(5). According to Arifin(8)economic business or empowerment carried out by pesantren generally involves four main things, namely: a. agriculture, b. animal husbandry, c. koperasi pesantren, $\mathrm{d}$. craft. These four things can be found in Ma'had AlZaytun. In fact, they also develop other fields that are used as their economic endeavors, such as: lodging or hotels, catering, laundry business and haircutting business.

\section{B. Food programs}

The Al-Zaytun food program began in March 2013 using around 760 bahu $(5.320 .000 \mathrm{~m} 2)$ of land that was turned into agricultural land (9). Initially the right to work was granted to the Ma'had Al-Zaytunacademic community: exponents, teachers and employees but then since the start of the food program was returned to Yayasan Pesantren Indonesia (YPI). YPI's business began by forming a community named P3KPI or 


\section{PaguyubanPetaniPenyanggaKetahananPangan}

Indonesia(the Indonesian Food Security Buffer Farmers Association) in February 2013. P3KPI was confirmed with Notarial Deed of Bambang Hariyanto $\mathrm{SH}$, number 64, dated 24 December 2014(10). P3KPI is a group of farmers engaged in agriculture and tasked with providing food, especially rice. P3KPI members are residents around Al-Zaytun who are able and have adequate experience in agriculture(10). Members of the P3KPI are people who are scattered in Gantar, Haurgeulis, Kroya and Bongas who are members of eight farmer groups(10). These local farmers (farmers from the Ma'had Al-Zaytun environment) can work on Al-Zaytun's land on the condition of being a member of the P3KPI and becoming a member of the KoperasiSerba Usaha (KSU) Desa Kota Indonesia (Multipurpose Koperasi (KSU) Village City Indonesia) managed by Al-Zaytun(10).

KSU Desa Kota Indonesia was officially established on the 12th of 12th 2012, based in Al-Zaytun, as a joint economic forum for moving villages to become rich sources of farmers and cities becoming dashing agricultural consumers(11) Farmers working on this land before working on the land must sign a Letter of Understanding (MoU) with Al-Zaytun as the land owner. The memorandum of understanding regulates the responsibilities for land and plants, caring for plants to obtain maximum results, profit sharing and capital loans for farming, and Al-Zaytun always provides guidance for the progress of farming(10). In the production sharing procedure agreed upon by the paron system, Al-Zaytun provides facilities in the form of loan funds for the cost of cultivation, seeds, fertilizers and other production facilities to the cost of harvesting. Cultivating farmers can borrow capital from Al-Zaytun without interest of approximately Rp 5.500.000/bahu. Capital is returned when harvesting. The harvest after capital is divided in two; half for farmers and half for Al-Zaytun. The farmers' share is mostly sold to Al-Zaytun at market prices and farmers are not burdened with land and building taxes. Land and building taxes are borne by Al-Zaytun(10).

As an illustration, in the 2013-2014 planting season (a matter of years the farming business starts from April to April the following year) Al-Zaytun has 408 bahu (285, 6 ha) and produces 1.833 tons of Milled Dry Grain (GKG) which is tilled by 72 P3KPI members. Every month AlZaytun must prepare 95-100 tons of GKG for the consumption of more than 7.500 residents consisting of students, volunteers and administrators. So, these results are enough to be consumed for 19.3 months, meaning they have a balance of 693 tons of GKG in that season. This balance is useful for food subsidies to all members of the KSU in the form of rice as much as $20 \mathrm{kp} /$ member/month at a price of Rp4.800/kg from 2014 to March 2015. The GKG balance increases each year to the food supply in 2015-2016 to 3.149 tons of GKG or equivalent to the adequacy of food for 33 months (2.8 years) and food subsidies to all members of the cooperative increased to $40 \mathrm{kp} / \mathrm{member} / \mathrm{month}$ at a price of Rp7.500/kg starting from 2015 to the month March 2016. Determination of the amount and price of subsidized rice based on deliberations by representatives of Koperasi members(10). In its implementation, the tiller farmers will be accompanied by field officers who are in charge of guiding from the time of opening the land, harvesting to entering the Al-Zaytun rice palace(10). In addition, farmers who get maximum results will get incentives/prizes. This is an example of food defence by Ma'had AL-Zaytun in relation to rice or staple food.

In addition to the above, guidance and counseling which is one of the items in the letter of understanding between the cultivating farmers and Al-Zaytun are always carried out by the Al-Zaytun well. Guidance and counseling carried out both before the planting season, planting, until the harvest. Guidance and counseling material including; technical guidance on planting and care, how to use loan funds to fit the use in the field, discipline as a sharecropper, to know yourself as a farmer whose work is very noble (10). Guidance and counseling is important to correct some of the mistakes that are commonly made by farmers who are technical in the field such as fertilizer problems. According to A S PanjiGumilang, one of the weaknesses of the national rice production system is the inappropriate use of fertilizers. Most farmers still use a single fertilizer such as urea, SP, or KCL even though in developed countries, agriculture uses compound fertilizer, such as; Australia and Egypt. With Australian compound fertilizer, each yields 11 tons per hectare. Compare with farmers in Indonesia who are still 4 tons per hectare(10). In addition, theological foundation is also a point that appears in this program. The theological foundation used by Shaykh PanjiGumilang to move the economy in Al-Zaytun is the words of Rasulullah SAW, "Antuma'lamu bi umuridunyakum." You better understand your world affairs. In addition, the motto of Nong fu guochiang from Kong Fu Tsu which means rich country-rich farmers and the words "al-fallahsayyidulbilad", farmers are state owners (10). All theological grounds especially those from the Prophet's hadith show that there is integration between Islam and the innovations of Ma'had Al-Zaytun.

C. Fisheries, animal husbandry, and food supply

In addition to rice, other fields of production of Ma'had Al-Zaytun are planting corn as a fulfillment of livestock feed and to be converted into soybean as a main food on Ma'had Al-Zaytun in the form of tofu or tempeh(10). In addition, there is also freshwater fish farming with a cage system, there is water treatment, there is a Frissian Holstein (FH) cattle farm for cow's milk production (daily milking), etawa goat and sheep cultivation, deer cultivation, silage processed food for animal feed, and animal feed industry for the needs of forage and concentrate (10). This shows that food defence and safety implemented by Ma'had al-Zaytun not only stopped in agriculture but also integrated with livestock and fisheries.

\section{Health and nutrition program}

Ma'had Al-Zaytun's food defence and safety program not only stopped at the level of production but was later implemented to the students. The benchmarks of success can then be seen from the health activities in Ma'had Al- 
Zaytun. These include every three months a health service (health unit) takes anthropometric measurements; to determine height and weight with the aim of monitoring the physical growth of the students(12). The results that then emerge can be said to be good. This can be seen from the table below:

TABLE I. RESULTS OF HEIGHT MEASUREMENTS BY AGE (TB / U)

\begin{tabular}{|l|l|l|l|}
\hline Time & Number of students & With growth disorder (percent) & Normal (percent) \\
\hline July 1999 & 1456 & $369(25,3 \%)$ & $1087(74,7 \%)$ \\
\hline April 2000 & 1452 & $358(24,5 \%)$ & $1098(75,5 \%)$
\end{tabular}

From the data above, there was an increase in students experiencing growth disorders of $0,8 \%$ (11 santri) in only that experienced normal growth from previously nine months. TABLE II. RESULT OF WEIGHT MEASUREMENTS BY HEIGHT(BB/TB):

\begin{tabular}{|l|l|l|l|l|}
\hline Time & $\begin{array}{l}\text { Number } \\
\text { students }\end{array}$ & Of & Obesity (percent) & Normal (percent) \\
\hline July 1999 & 1456 & $162(11,1 \%)$ & $49(3,4 \%)$ & $1245(85,5 \%)$ \\
\hline April 2000 & 1452 & $93(6,3 \%)$ & $34(2,3 \%)$ & $1327(91,3 \%)$ \\
\hline
\end{tabular}

From the data above, there was an increase in students who gained normal weight (proportional) of 5.8\% (82 students). The average weight gain for nine months (July 1999-April 2000) is 4-5 kg for rijal students and 3-4 kg for nisa' students. In addition to antrometry measurements every three months, there are also provisions about the minimum calories that must be eaten every day; 2,500 calories. From the above data it can be seen that the Ma'had Al-Zaytun food security defence and safety program is integrated with the health and nutrition unit to prove that what they produce is not only good in terms of quantity but also good in terms of quality.

E. Agricultural education program

The last effort made by Ma'had Al-Zaytun for food defence and safety is the existence of an educational program in agriculture. The program is named Program pendidikanPertanianTerpadu(P3T) or the Integrated Agricultural Education Program. This diploma level program was inaugurated by $\mathrm{A} S$ PanjiGumilang on January 1, 2000, to coincide with the 25th of Ramadan 1420 H. (13). This non-degree program requires 18 months of study time divided into four semesters with 85 Semester Credit Systems (SKS). In the first year the program was attended by 76 students coming from provinces in Java. While participating in the program, they live in a dormitory and after graduating, these students will be seconded by YPI to manage waqaflands owned by YPI. The aim is to independently fulfill the food needs of all residents of Ma'had Al-Zaytun(13).

P3T has a comparison between field practice and supporting theory is 70 versus 30 . This means that in addition to practicum students are also given practical support theories. Practical here means directed and systematic to support field practice. The courses in this program are in the first semester given Applied Biology, Applied Physics, Applied Mathematics, Applied Chemistry, General Agronomy, Agro-Climatology and Philosophy of Science. Furthermore, in the second semester the courses given are more technical in nature such as Dairy Farming, Feed Introduction and Feeding, Aquatic Environment, Soil and Fertilization, Food Crops, and Meat Livestock Cultivation.

The practicum land owned by this program is 5 hectares. For plantations in July 2000, 300.000 gold teak trees were planted, livestock already provided housing, both cows, dairy goats and meat, to milking areas to cow's milk processing. For fisheries, there are already four fish ponds that have developed catfish, red tilapia, and pomfret. There is even a hatchery and spawning labarotarium which in the first phase of each month has a capacity of 500,000 nurseries(12).

\section{CONCLUSION}

Ma'had Al-Zaytun's food defence and safety program can be traced from several programs that have been and continue to take place, including food, animal husbandry and fisheries programs, agricultural education programs that integrated with health and nutrition programs. All these programs are carried out systematically through the collaboration of all lines, both kiai (A S Panji Gumilang), santri/students, and the surrounding community. The success of the program can also be seen from the growth and normal proportion of students' body weight after nine months living in this pesantren. The food defence and safety model that Ma'had Al-Zaytun has been able to continue to be one of the models for food self-sufficiency both at the regional and national levels.

[1] UU no 18 tahun 2012

[2] GFSI. GFSI Benchmarking requirements version 7.2 (draft 2017). 2017

[3] EU. Regulation (EC) No 178/2002 of the European Parliament and of the Council of 28 January 2002 laying down the general principles and requirements of food law, establishing the European Food Safety Authority and laying down procedures in matters of food safety. J Eur Communities. 2002;31.

[4] Davidson R, Belenguer J, Antunez W, Gerevini M. From Food Defence to Food Supply Chain Integrity. Br Food J. 2017;

[5] Ismail S. Strategi Mewujudkan Kemandirian Pesantren Berbasis Pemberdayaan Santri. J Perspekt Sosiol. 2016;4(1).

[6] Faozan A. Pondok Pesantren dan Pemberdayaan Ekonomi. J Studi Agama Dan Budaya Ibda'. 2006;4(1).

[7] Tabroni R. Sistem Pendidikan Satu Pipa Ma'had Al-Zaytun Indramayu. Edukasia J Penelit Pendidik Islam. 2018;13(2).

[8] Arifin S, Harijito DA, Suparwoko. Studi Potensi Ekonomi dan Kebutuhan Pondok Pesantren se-Karesidenan Kedu Jawa Tengah. J Fenom. 2008;6(1).

[9] Yayasan Pesantren Indonesia Al-Zaytun. Al-Zaytun: Pusat Pendidikan Pengembangan Budaya Toleransi dan Perdamaian. Indramayu: Yayasan Pesantren Indonesia; 2014.

[10] Simanullang R. Al-Zaytun: Sumber Inspirasi Bermasyarakat, Berbangsa dan Bernegara. Jakarta: Pustaka Tokoh Indonesia; 2015.

[11] Za'eem A dan AA-H. Majalah Berita Indonesia. 87th ed. Indramayu: Yayasan Pesantren Indonesia; 2013.

[12] Za'eem A dan AA-H. Majalah Al-Zaytun. 10th ed. Indramayu: Yayasan Pesantren Indonesia; 2000.

[13] Za'eem A dan AA-H. Majalah Al-Zaytun. 01 ed. Indramayu: Yayasan Pesantren Indonesia; 2000. 